\title{
Retraction Note to: Prediction of coastal rainfall trend and development of coastal leisure sports based on remote sensing image processing
}

\author{
Fei Zeng ${ }^{1}$
}

Published online: 12 November 2021

(c) Saudi Society for Geosciences 2021

Retraction Note to: Arabian Journal of Geosciences (2021) 14: 938 https://doi.org/10.1007/s12517-021-07198-w

The Editor-in-Chief and the Publisher have retracted this article because the content of this article is nonsensical. The peer review process was not carried out in accordance with the Publisher's peer review policy. The author has not responded to correspondence regarding this retraction.

The original article can be found online at https://doi.org/10.1007/ s12517-021-07198-w.

Fei Zeng

zengfei5988@163.com

1 Department of Physical Education, Wuchang Institute of Technology, WuHan 430065, HuBei, China 